\title{
Method for the Separation of Titanium, Zirconium, Iron, and Aluminum from One Another and for their Subse- quent Determination
}

\author{
Thomas J. Murphy, W. Stanley Clabaugh, and Raleigh Gilchrist
}

(August 5, 1960)

\begin{abstract}
A method is described for the separation of titanium, zirconium, iron, and aluminum from one another and for their subsequent determination. Iron is first precipitated with 1-nitroso-2-naphthol after complexing the titanium and zirconium with citrate to prevent their precipitation. Titanium and zirconium are then collectively precipitated with cupferron and subsequently separated from each other by precipitating the titanium with 8-hydroxyquinoline after complexing the zirconium with ethylenediaminetetraacetic acid. Aluminum and zirconium are recovered from their respective solutions by precipitation with cupferron.

The accuracy of the method was proved by analyzing synthetic solutions containing known amounts of the four elements.
\end{abstract}

\section{Introduction}

This paper describes the separation and determination of titanium, zirconium, iron, and aluminum in barium titanate ceramic dielectrics. These ceramic dielectrics may be dissolved by digestion on the steam bath overnight in a solution containing equal volumes of hydrochloric acid and water. Any undissolved residue may be brought into solution by fusing it with sodium carbonate and treating the resulting fusion with diluted hydrochloric acid. Titanium, zirconium, iron, and aluminum can then be sharply separated from the alkaline earths, the alkalies, and silicon by a double precipitation with 8-hydroxyquinoline.

The procedure described here starts with the collective precipitation of the four elements by 8-hydroxyquinoline. Much of the analytical chemistry involved is new and should have application to analytical problems other than those of ceramic dielectrics.

\section{Reagents}

Standard Titanium Solution: Fifty milliliters of titanium tetrachloride, purified according to the directions of Clabaugh, Leslie, and Gilchrist [1], ${ }^{2}$ was slowly added to $100 \mathrm{ml}$ of ice cold water. The resulting solution was diluted to 2.5 liters with diluted hydrochloric acid $(1+1) .^{3} \quad$ Three 50 -g portions of this diluted solution, measured with a weight buret, were each diluted to $250 \mathrm{ml}$ and the titanium content

Financial support of this work was furnished by the Diamond Ordnance Fuze Laboratories, Department of the Army, Washington 25, D.C.

Figures in brackets indicate the literature references at the end of this paper. When the use of an acid is prescribed with no indication of strength or dilution, the acid to be used is the concentrated acid. Dilutions are indicated by the volumes of acid and water mixed to prepare a diluted reagent. Diluted hydrochloric acid $(1+x)$ means a diluted acid prepared by mixing 1 volume of the concentrated acid (1 $x$ ) molumes of distilled water. Similer designations are used for am nium hydroxide. determined by precipitating with cupferron and igniting the precipitate to $\mathrm{TiO}_{2}$.

Standard Iron Solution: About $20 \mathrm{~g}$ of ferric chloride hexahydrate, American Chemical Society Reagent grade, was dissolved in $200 \mathrm{ml}$ of diluted hydrochloric acid $(1+1)$. The resulting solution was diluted to 2 liters with water. The titer was determined in a manner similar to that for titanium.

Standard Zirconium Solution: About $65 \mathrm{~g}$ of zirconium sulfate tetrahydrate, purified according to the procedure described by Clabaugh and Gilchrist [2], was dissolved in 1 liter of diluted hydrochloric acid $(1+3)$ and the resulting solution then diluted to 2 liters with diluted hydrochloric acid $(1+3)$. The titer was determined in a manner similar to that for titanium. This titer also includes any hafnium present in the zirconium.

Standard Aluminum Solution: About $4 \mathrm{~g}$ of pure metallic aluminum was dissolved in $400 \mathrm{ml}$ of diluted hydrochloric acid $(1+2)$ and the resulting solution then diluted to 2 liters with water. Three $50-\mathrm{g}$ portions of this diluted solution, measured with a weight buret, were each diluted to $250 \mathrm{ml}$. To each of these solutions $10 \mathrm{ml}$ of acetic acid was added. The acidity was then reduced to value of $p H$ 5.0 with diluted ammonium hydroxide $(1+1)$. The aluminum content was determined by precipitating with 8-hydroxyquinoline and igniting the precipitate to $\mathrm{Al}_{2} \mathrm{O}_{3}$.

1-Nitroso-2-Naphthol Reagent Solution: Commercially available samples of 1-nitroso-2-naphthol were found to contain significant amounts of residue on ignition. For three different samples the residues amounted to 0.07 percent, 0.14 percent, and 0.19 percent. Spectrochemical examination of one of the residues showed that it was primarily $\mathrm{Fe}_{2} \mathrm{O}_{3}$, and also contained about 10 percent each of $\mathrm{MgO}$ and $\mathrm{SiO}_{2}$.

Five grams of 1-nitroso-2-naphthol was placed in a 25-ml porous porcelain filtering crucible and 
leached with $800 \mathrm{ml}$ of water heated to $60^{\circ} \mathrm{C}$. This treatment dissolved about $0.5 \mathrm{~g}$ of the reagent. Five hundread $\mathrm{ml}$ of diluted ethanol $(1+1)$, heated to about $60{ }^{\circ} \mathrm{C}$, was then passed through the filter and this dissolved most of the water-washed material. The porcelain filter and residue were air-dried and weighed. The concentration of the reagent in the alcoholic solution was determined by difference. This treatment reduced the residue on ignition from 0.07 to 0.01 percent. This reagent solution must be freshly prepared since it decomposes on standing.

Cupferron Reagent Solution: Five grams of cupferron, the ammonium salt of nitrosophenylhydroxylamine, was dissolved in $100 \mathrm{ml}$ of water. This solution must be freshly prepared since it decomposes on standing.

Ammonium Acetate Reagent Solution: Five hundred milliliters of acetic acid was cooled in an ice bath and ammonium hydroxide was slowly added to the cold solution until the $p \mathrm{H}$ of the resulting solution was $7 .^{4}$

Ethylenediaminetetraacetic Acid: To prepare ethylenediaminetetraacetic acid suitable for use, the practical grade was dissolved in a solution of ammonium hydroxide. This solution was filtered and then neutralized to $p \mathrm{H} 1$ with hydrochloric acid to reprecipitate the ethylenediaminetetraacetic acid. The precipitate was caught on a filter, washed well with distilled water, and dried at $100{ }^{\circ} \mathrm{C}$.

Other Reagents: All the other reagents used conformed to the specifications of the American Chemical Society for reagent chemicals.

\section{Development of the Procedure}

\subsection{Separation of Iron From Titanium, Zirconium, and Aluminum}

Ferric iron is reported to be quantitatively precipitated by 1-nitroso-2-naphthol, $\left(\mathrm{C}_{10} \mathrm{H}_{7} \mathrm{O}_{2} \mathrm{~N}\right)$, in the $p \mathrm{H}$ range 0.95 to 2.00 [3]. The iron is precipitated as ferric nitrosonaphtholate [4], $\mathrm{Fe}\left(\mathrm{C}_{10} \mathrm{H}_{6} \mathrm{O}_{2} \mathrm{~N}\right)_{3}$, which can be ignited to ferric oxide [5], $\mathrm{Fe}_{2} \mathrm{O}_{3}$. Titanium and zirconium are also reported to precipitate with 1-nitroso-2-naphthol from weak acid solutions [6]. Aluminum does not form an insoluble precipitate with 1-nitroso-2-naphthol.

Citrate ion was found to prevent the precipitation of titanium and zirconium nitrosonaphtholates from weakly acid solution, at about $p \mathrm{H}$ 1.5. Ferric iron was found to precipitate quantitatively from a citrate solution in the $p \mathrm{H}$ range 1.0 to 2.0 . Since aluminum is not precipitated by 1-nitroso-2-naphthol, and since citrate ion prevents the precipitation of titanium and zirconium, the possibility of separating iron from these elements by the precipitation of ferric nitrosonaphtholate from a citrate solution was investigated.

It was found that when precipitations of iron were attempted from solutions having a volume of about $350 \mathrm{ml}$ and containing $500 \mathrm{mg}$ of $\mathrm{TiO}_{2}$ and $50 \mathrm{mg}$ of

${ }^{4}$ All $p H$ measurements were made with a glass-electrode $p H$ meter.
$\mathrm{Fe}_{2} \mathrm{O}_{3}$, or $500 \mathrm{mg}$ of $\mathrm{ZrO}_{2}$ and $50 \mathrm{mg}$ of $\mathrm{Fe}_{2} \mathrm{O}_{3}$, or $500 \mathrm{mg}$ of $\mathrm{Al}_{2} \mathrm{O}_{3}$ and $50 \mathrm{mg}$ of $\mathrm{Fe}_{2} \mathrm{O}_{3}$, the results were always high. This was thought to be due to the fact that 1-nitroso-2-naphthol is not very soluble under these conditions and that the ferric nitrosonaphtholate forms so slowly that most of the 1-nitroso-2-naphthol precipitates from solution and adsorbs some of the metallic ions. Ethanol increased the solubility of 1-nitroso-2-naphthol and improved the separation, provided that the ethanol content did not exceed $75 \mathrm{ml}$ of 95 -percent ethanol in $350 \mathrm{ml}$ of solution and provided that at least a 0.2 -g excess of 1-nitroso-2-naphthol was present. If more ethanol or less 1-nitroso-2-naphthol were present, the precipitation of iron was not complete.

\section{a. Separation of Iron From Titanium}

Eight synthetic mixtures of iron and titanium were prepared from the respective standard solutions. Each solution contained an amount of titanium equivalent to $500 \mathrm{mg}$ of $\mathrm{TiO}_{2}$ and an amount of iron equivalent to from $0.2 \mathrm{mg}$ to $50 \mathrm{mg}$ of $\mathrm{Fe}_{2} \mathrm{O}_{3}$. Ten grams of citric acid and $1.8 \mathrm{~g}$ of 8-hydroxyquinoline were added to each solution. The citric acid was added to complex the titanium. The 8-hydroxyquinoline was added to approximate the amount of this reagent that would be present if the mixture was first precipitated with 8-hydroxyquinoline to separate this group of elements from the alkalies and alkaline earths and then taken into solution as. described in section 4.1.

The acidity of each solution was adjusted to $p \mathrm{H}$ 1.5 with diluted ammonium hydroxide $(1+1)$, and then the iron was precipitated with 1-nitroso-2naphthol reagent solution as described in section 4.2.

The results of these separations are given in table 1.

TABLE 1. Results cbtained in the separation of iron from. titanium by 1-nitroso-2-naphthol

\begin{tabular}{|c|c|c|c|c|}
\hline \multirow{2}{*}{$\begin{array}{l}\text { Experi- } \\
\text { ment }\end{array}$} & \multirow{2}{*}{$\begin{array}{c}\begin{array}{c}\text { Titanium } \\
\text { dioxide }\end{array} \\
\text { Added }\end{array}$} & \multicolumn{3}{|c|}{ Ferric oxide } \\
\hline & & Added & Found & Error \\
\hline & $m g$ & $m g$ & $m g$ & $m g$ \\
\hline $1 \ldots$ & 500 & 0.2 & 0.2 & 0.0 \\
\hline $2 \ldots$ & 500 & .5 & .5 & 0 \\
\hline 3. & 500 & 2.5 & 2. 6 & +.1 \\
\hline & 500 & 4. 1 & 4.3 & +.2 \\
\hline & 530 & 5. 1 & 5. 2 & +.1 \\
\hline $6 \ldots$ & 570 & 11. 2 & 11.3 & +.1 \\
\hline & 507 & 23.4 & 23.6 & +.2 \\
\hline $8 \ldots \ldots$ & 500 & 48.8 & 48. ? & +.1 \\
\hline
\end{tabular}

Chemical analysis of $50 \mathrm{mg}$ of $\mathrm{Fe}_{2} \mathrm{O}_{3}$, separated from $500 \mathrm{mg}$ of $\mathrm{TiO}_{2}$, showed that the $\mathrm{Fe}_{2} \mathrm{O}_{3}$ contained slightly more than $0.1 \mathrm{mg}$, but less than 0.2 $\mathrm{mg}$ of $\mathrm{TiO}_{2}$.

\section{b. Separation of Iron From Zirconium}

Five synthetic mixtures of iron and zirconium were prepared from the respective standard solutions. Each solution contained an amount of zir- 
conium equivalent to $500 \mathrm{mg}$ of $\mathrm{ZrO}_{2}$ and an amount of iron equivalent to from $0.5 \mathrm{mg}$ to $50 \mathrm{mg}$ of $\mathrm{Fe}_{2} \mathrm{O}_{3}$.

The synthetic mixtures were treated exactly as the iron-titanium mixtures in section a, and the iron in each solution was separated and determined by the method described in section 4.2. 2 .

The results of these separations are given in table TABLE 2. Results obtained in the separation of iron from
zirconium by 1-nitroso-2-naphthol

\begin{tabular}{|c|c|c|c|c|}
\hline \multirow{2}{*}{$\begin{array}{c}\text { Experi- } \\
\text { ment }\end{array}$} & \multirow{2}{*}{$\frac{\begin{array}{c}\text { Zirconium } \\
\text { dioxide }\end{array}}{\text { Added }}$} & \multicolumn{3}{|c|}{ Ferric oxide } \\
\hline & & Added & Found & Error \\
\hline 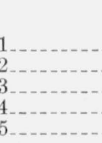 & $\begin{array}{l}m g \\
500 \\
500 \\
500 \\
500 \\
500\end{array}$ & \begin{tabular}{r}
\multicolumn{1}{c}{$m g$} \\
0.5 \\
2.6 \\
11.1 \\
24.0 \\
51.4
\end{tabular} & \begin{tabular}{r}
\multicolumn{1}{c}{$m g$} \\
0.5 \\
2.6 \\
11.0 \\
24.1 \\
51.6
\end{tabular} & $\begin{array}{r}m g \\
0.0 \\
.0 \\
-.1 \\
+.1 \\
+.2\end{array}$ \\
\hline
\end{tabular}

Chemical analysis of $50 \mathrm{mg}$ of $\mathrm{Fe}_{2} \mathrm{O}_{3}$, separated from $500 \mathrm{mg}$ of $\mathrm{ZrO}_{2}$, showed that the ferric oxide contained about $0.1 \mathrm{mg}$ of $\mathrm{ZrO}_{2}$.

\section{c. Separation of Iron From Aluminum}

Five synthetic mixtures of iron and aluminum were prepared from the respective standard solutions. Each solution contained an amount of aluminum equivalent to $500 \mathrm{mg}$ of $\mathrm{Al}_{2} \mathrm{O}_{3}$ and an amount of iron equivalent to from $0.5 \mathrm{mg}$ to $50 \mathrm{mg}$ of $\mathrm{Fe}_{2} \mathrm{O}_{3}$.

The synthetic mixtures were treated exactly as the iron-titanium mixtures in section $a$, and the iron in each solution was separated and determined by the method described in section 4.2 .

The results of these separations are given in table 3 .

TABLE 3. Results obtained in the separation of iron from aluminum by 1-nitroso-2-naphthol

\begin{tabular}{|c|c|c|c|c|}
\hline \multirow{2}{*}{$\begin{array}{c}\text { Experi- } \\
\text { ment }\end{array}$} & \multirow{2}{*}{$\begin{array}{l}\begin{array}{c}\text { Alumi- } \\
\text { num } \\
\text { oxide }\end{array} \\
\text { Added }\end{array}$} & \multicolumn{3}{|c|}{ Ferric oxide } \\
\hline & & Added & Found & Error \\
\hline & $m g$ & $m g$ & $m g$ & $m g$ \\
\hline & 500 & 0.5 & 0.6 & +0.1 \\
\hline 2 & 500 & 2.5 & 2.6 & +.1 \\
\hline $3 \ldots \ldots$ & 500 & 10.2 & 10.3 & +.1 \\
\hline & 500 & 24.6 & 24.5 & -.1 \\
\hline & 500 & 50.5 & 50.4 & -.1 \\
\hline
\end{tabular}

Chemical analysis of $50 \mathrm{mg}$ of $\mathrm{Fe}_{2} \mathrm{O}_{3}$, separated from $500 \mathrm{mg}$ of $\mathrm{Al}_{2} \mathrm{O}_{3}$, showed that the ferric oxide contained about $0.1 \mathrm{mg}$ of $\mathrm{Al}_{2} \mathrm{O}_{3}$.

\subsection{Separation of Titanium and Zirconium From Aluminum}

Titanium and zirconium are reported to be quantitatively separated from aluminum by precipitation with cupferron from strongly acidic solution [7]. Titanium is precipitated as titanium cupferrate [8], $\mathrm{Ti}\left(\mathrm{C}_{6} \mathrm{H}_{5} \mathrm{~N}_{2} \mathrm{O}_{2}\right)_{4}$, which can be ignited to $\mathrm{TiO}_{2}$. The literature does not report the formula of the zirconium cupferrate, but, by analogy, it is probably $\mathrm{Zr}\left(\mathrm{C}_{6} \mathrm{H}_{5} \mathrm{~N}_{2} \mathrm{O}_{2}\right)_{4}$, which can be ignited to zirconium dioxide [9], $\mathrm{ZrO}_{2}$.

Synthetic mixtures containing $50 \mathrm{mg}$ of $\mathrm{Al}_{2} \mathrm{O}_{3}$ and $500 \mathrm{mg}$ of $\mathrm{TiO}_{2}$, and synthetic mixtures containing $50 \mathrm{mg}$ of $\mathrm{Al}_{2} \mathrm{O}_{3}$ and $500 \mathrm{mg}$ of $\mathrm{ZrO}_{2}$ were prepared from their respective standard solutions and the volumes adjusted to approximately $400 \mathrm{ml}$. Ten grams of citric acid was added to each solution, the solutions were neutralized to $p \mathrm{H} 1.5$ with diluted ammonium hydroxide $(1+1)$, and $50 \mathrm{ml}$ of hydrochloric acid added to each. A sufficient quantity of cupferron reagent solution was added to each solution to precipitate the titanium or zirconium and provide about $10 \mathrm{ml}, 0.5$ gram of cupferron, in excess. The solutions were allowed to stand in a refrigerator for about $4 \mathrm{hr}$ and were filtered through $12.5-\mathrm{cm}$ papers. ${ }^{5}$ The filters and pracipitates ware washed with a 0.1 -percent solution of cupferron in diluted hydrochloric acid $(1+9)$, then transferred to $150-\mathrm{ml}$ beakers and decomposed by heating with an infrared lamp. The beakers were then placed in an electric furnace at $450^{\circ} \mathrm{C}$ and maintained at this temperature overnight or until there was no visible evidence of carbon. The beakers were gradually cooled to room temperature, and $30 \mathrm{ml}$ of diluted sulfuric acid $(1+1)$ was added to each. The beakers were covered and heated gently on an electric hot plate until the oxides were dissolved. The solutions were cooled, transferred to $600-\mathrm{ml}$ beakers, and diluted to $400 \mathrm{ml}$ with water.

The titanium or zirconium in each solution was reprecipitated, filtered, and washed as described above. To determine the amount of alumioum that contaminated the first precipitate, the filtrates from the second precipitation of titanium or zirconium were cooled in an ice bath and their acidities adjusted to $p \mathrm{H} 4.0$ with ammonium hydroxide. The solutions, after standing overnight in a refrigerator. were filtered through 9-cm papers, and the precipitates were washed with a 0.5 -percent aqueous solution of cupferron, ignited in porcelain crucibles, and weighed as $\mathrm{Al}_{2} \mathrm{O}_{3}$. The results, given in table 4, show that a considerable amount of aluminum bad precipitated with the first titanium or zirconium cupferrates.

TABLE 4. Comparison of results obtained by varying the conditions of precipitation in the separation of titanium and zirconium from aluminum by cupferron

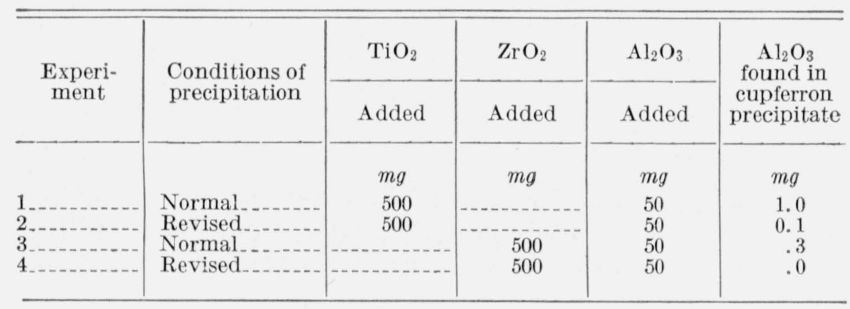

${ }^{5}$ All filter paper used was quantitative, ashless filter paper of close, dense texture suitable for retaining the finest precipitates. 
It was found, however, that if slightly less cupferron than the amount necessary to precipitate completely the titanium or zirconium was added, and the solution heated to about $60^{\circ} \mathrm{C}$ and stirred continually, the precipitated cupferrates changed from a bulky, flocculent form to a dense and compact form. The precipitation of titanium or zirconium was then completed by the slow addition of cupferron reagent solution until a permanent precipitate no longer formed. Finally, the solutions were cooled and an additional $10 \mathrm{ml}$ of the cupferron reagent solution was added to each.

Figure 1 shows a comparison of the volumes of equal amounts of titanium precipitated with cupferron by the normal method and by the revised method. Figure 2 shows a similar comparison in the case of zirconium. The amounts of titanium and of zirconium involved were equivalent to 500 $\mathrm{mg}$ of their respective dioxides.

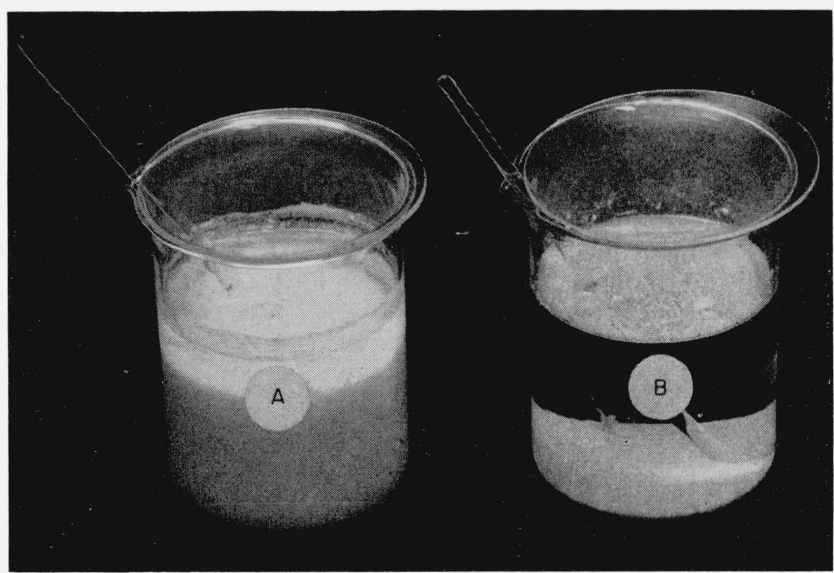

Figure 1. Comparison of the volumes of equal amounts of titanium precipitated with cupferron by the normal method, $A$, and the revised method, $B$.

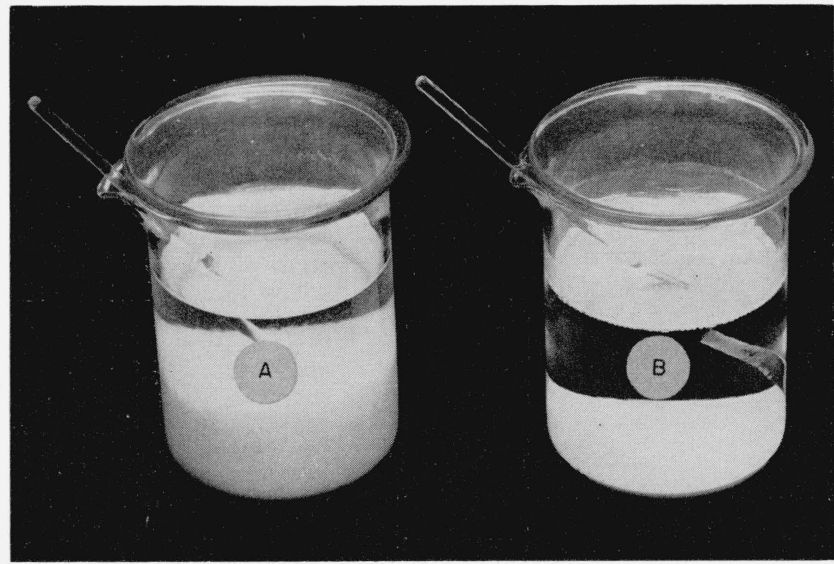

Figure 2. Comparison of the volumes of equal amounts of zirconium precipitated with cupferron by the normal method, $A$, and the revised method, $B$.
It was reasoned that since the volumes of the precipitates were much smaller by the revised method of precipitation, a better separation of titanium and zirconium from aluminum might be effected. Synthetic mixtures containing $50 \mathrm{mg}$ of $\mathrm{Al}_{2} \mathrm{O}_{3}$ and $500 \mathrm{mg}$ of $\mathrm{TiO}_{2}$, and also mixtures containing 50 $\mathrm{mg}$ of $\mathrm{Al}_{2} \mathrm{O}_{3}$ and $500 \mathrm{mg}$ of $\mathrm{ZrO}_{2}$, were prepared from the standard solutions. The separations were effected by the revised procedure described above. The results, also reported in table 4 , show that the amount of aluminum that was precipitated with the titanium and zirconium was significantly reduced.

\subsection{Recovery and Determination of Aluminum}

Aluminum is reported to be quantitatively precipitated by cupferron from weakly acid solution, probably as $\mathrm{Al}\left(\mathrm{C}_{6} \mathrm{H}_{5} \mathrm{~N}_{2} \mathrm{O}_{2}\right)_{3}$. This compound can be ignited to [10] $\mathrm{Al}_{2} \mathrm{O}_{3}$.

The completeness of precipitation of aluminum by cupferron from a solution containing large amounts of ammonium chloride and ammonium citrate was determined by the analyses of four synthetic solutions of aluminum containing from $0.5 \mathrm{mg}$ to $50 \mathrm{mg}$ of $\mathrm{Al}_{2} \mathrm{O}_{3}$ which were prepared from the standard solutions. Ten grams of citric acid and $50 \mathrm{ml}$ of hydrochloric acid were added to each solution and the solutions were then diluted to $400 \mathrm{ml}$. The acidity of each solution was adjusted to $p \mathrm{H} 4.0$ with ammonium hydroxide. Enough cupferron reagent solution was added to furnish a 1-g excess of cupferron. The solutions were allowed to stand overnight in a cold box. The precipitates were caught on $12.5-\mathrm{cm}$ papers, washed with a 1-percent solution of cupferron, and ignited to $\mathrm{Al}_{2} \mathrm{O}_{3}$ in porcelain crucibles at $1,100{ }^{\circ} \mathrm{C}$.

The results of these determinations are given in table 5. In each instance the recovery of the added aluminum was complete.

TABLE 5. Recovery of aluminum by precipitation with cupferron

\begin{tabular}{l|c|c|c}
\hline \hline \multirow{2}{*}{$\begin{array}{c}\text { Experi- } \\
\text { ment }\end{array}$} & \multicolumn{3}{|c}{ Aluminum Oxide } \\
& Added & Found & Error \\
\hline & & & \\
\hline & $m g$ & $m g$ & $m g$ \\
1 & 0.5 & 0.5 & 0.0 \\
3 & 4.8 & 4.7 & -.1 \\
4 & 23.4 & 23.3 & -.1 \\
& 51.5 & 51.7 & +.2 \\
\hline
\end{tabular}

\subsection{Separation of Titanium From Zirconium}

In weakly acid solution, ethylenediaminetetraacetic acid forms a strong mole-to-mole complex with zirconium [11] and a weaker one with titanium [12]. Sen Sarma and Mallik [13] state that the zirconium complex is strong enough to prevent the precipitation of zirconium by 8-hydroxyquinoline in weakly acid solution. Experiments in our laboratory showed that titanium could be almost completely precipitated as titanyl quinolate, TiO- 
$\left(\mathrm{C}_{9} \mathrm{H}_{6} \mathrm{NO}\right)_{2} \cdot 2 \mathrm{H}_{2} \mathrm{O}$, at $p \mathrm{H} 4.5$ in the presence of ethylenediaminetetraacetic acid, under certain conditions. A 1-g excess of 8-hydroxyquinoline over the amount necessary to precipitate the titanyl quinolate must be present. The excess of ethylenediaminetetraacetic acid should not be greater than $0.5 \mathrm{~g}$ over the amount needed to complex the zirconium. The solution should be cooled in an ice bath before filtering. When these conditions are observed, the amount of titanium remaining in solution was found to be about $0.05 \mathrm{mg}$ as $\mathrm{TiO}_{2}$. This solubility of titanium was low enough to regard the precipitation as complete.

The titanyl quinolate precipitate can be decomposed by heat from an infrared lamp and converted to $\mathrm{TiO}_{2}$ by ignition in an electric furnace. Berg and Teitelbaum [14] reported that this decomposition should be done under a layer of oxalic acid, because of the volatility of titanyl quinolate. Arend and Schnellenbach [15] used a direct decomposition and ignition of titanyl quinolate without the addition of oxalic acid. Experiments in our laboratory showed that when the decomposition was performed with heat from an infrared lamp, no titanyl quinolate was volatilized. Known amounts of titanium were precipitated by 8-hydroxyquinoline, decomposed by heat from an infrared lamp, and ignited to $\mathrm{TiO}_{2}$ without any loss of titanium. No trace of titanium was found when the decomposition products from heating titanyl quinolate with an infrared lamp were passed through a solution of sulfuric acid.

Synthetic solutions containing from $475 \mathrm{mg}$ of $\mathrm{TiO}_{2}$ and $25 \mathrm{mg}$ of $\mathrm{ZrO}_{2}$ to $100 \mathrm{mg}$ of $\mathrm{TiO}_{2}$ and 400 $\mathrm{mg}$ of $\mathrm{ZrO}_{2}$ were prepared from the standard solutions. These mixtures were converted to sulfates by the addition of $15 \mathrm{ml}$ of sulfuric acid and subsequent evaporation to fumes of sulfuric acid. Each solution was then treated as described in section 4.5. Each precipitate of titanyl quinolate was dissolved in 100 $\mathrm{ml}$ of diluted sulfuric acid $(15+85)$ and the titanium reprecipitated. To determine the contamination of the first precipitate by zirconium, the filtrates from the second precipitation were made acid with hydrochloric acid and the zirconium recovered by precipitation with cupferron. The solutions were allowed to stand for about $4 \mathrm{hr}$ and filtered through $9-\mathrm{cm}$ papers. The filters and precipitates were washed with a solution of cupferron, transferred to porcelain crucibles, decomposed by an infrared lamp, and ignited to $\mathrm{ZrO}_{2}$ at $1000{ }^{\circ} \mathrm{C}$.

The degree of contamination of the titanyl quinolate by zirconium, over the range studied, is given in table 6 .

The separation was satisfactory up to the concentration range of about $200 \mathrm{mg}$ of $\mathrm{TiO}_{2}$ and 300 $\mathrm{mg}$ of $\mathrm{ZrO}_{2}$. For amounts of zirconium in excess of this amount a double precipitation should bs made, but this increases the amount of soluble titanium weighed with the $\mathrm{ZrO}_{2}$ to $0.1 \mathrm{mg}$ of $\mathrm{TiO}_{2}$.

Eight synthetic mixtures of titanium and zirconium were prepared from the standard solutions. Fifteen milliliters of sulfuric acid was added to each and the
TABLE 6. Experiments which show the degree of contamination of titanium quinolate by zirconium

\begin{tabular}{c|c|c|c}
\hline \hline \multirow{2}{*}{$\begin{array}{c}\text { Experi- } \\
\text { ment }\end{array}$} & TiO & $\mathrm{ZrO}_{2}$ & $\begin{array}{c}\mathrm{ZrO}_{2} \text { found } \\
\text { in Ti } \\
\text { precipitate }\end{array}$ \\
& Added & Added & \\
& & & \\
& $m g$ & $m g$ & $m g$ \\
1 & 475 & 25 & 0.0 \\
2 & 450 & 50 & .0 \\
3 & 425 & 75 & .0 \\
4 & 400 & 100 & .1 \\
5 & 300 & 200 & .1 \\
6 & 200 & 300 & .4 \\
7 & 100 & 400 & \\
\hline
\end{tabular}

solutions were evaporated to fumes of sulfuric acid. The titanium was then separated and determined by the procedure described in section 4.5. The filtrates were reserved for the determination of zirconium according to the directions in section 3.5. The results of these separations and determinations are given in table 7 .

TABLE 7. Results obtained in the separation of titanium from zirconium by precipitation with 8-hydroxyquinoline in a solution containing ethylenediaminetetraacetic acid

\begin{tabular}{|c|c|c|c|c|c|c|}
\hline \multirow{2}{*}{$\begin{array}{l}\text { Experi- } \\
\text { ment No. }\end{array}$} & \multicolumn{3}{|c|}{ Titanium dioxide } & \multicolumn{3}{|c|}{ Zirconium dioxide } \\
\hline & Added & Found & Error & Added & Found & Error \\
\hline & $g$ & $g$ & $m g$ & $g$ & $g$ & $m g$ \\
\hline 1. & 0.5037 & 0.5037 & 0.0 & 0.0005 & 0.0006 & +0.1 \\
\hline 2 & .4981 & .4984 & +.3 & .0009 & .0009 & 0 \\
\hline & .4831 & .4830 & -.1 & .0067 & .0066 & -.1 \\
\hline & .4808 & .4809 & +.1 & .0093 & .0092 & -.1 \\
\hline & .4605 & .4608 & +.3 & .0268 & .0268 & .0 \\
\hline $6 \ldots$ & .4468 & .4471 & +.3 & .0606 & .0604 & -.2 \\
\hline & .3941 & .3944 & +.3 & .1035 & .1035 & .0 \\
\hline & .2905 & .2907 & +.2 & .2185 & .2185 & .0 \\
\hline
\end{tabular}

\subsection{Recovery and Determination of Zirconium}

Majumdar and Chowdhury [16] reported that, in the presence of ethylenediaminetetraacetic acid, zirconium can be quantitatively precipitated by cupferron from hydrochloric acid solution.

To confirm this observation, five solutions containing known amounts of zirconium in the range of $0.5 \mathrm{mg}$ to $55 \mathrm{mg}$ of $\mathrm{ZrO}_{2}$ were prepared. Fifteen milliliters of sulfuric acid was added to each solution and enough ethylenediaminetetraacetic acid to furnish a $0.5-\mathrm{g}$ excess over the amount necessary to complex the zirconium. The acidity of each solution was adjusted to $p \mathrm{H} 1.5$ with ammonium hydroxide, and then to $p \mathrm{H} 4.5$ with the ammonium acetate reagent solution. Fifty milliliters of hydrochloric acid was added to each solution and enough cupferron to furnish an excess of $1 \mathrm{~g}$. The solutions were allowed to stand overnight in a cold box, then filtered through $12.5-\mathrm{cm}$ papers. The filters and precipitates were decomposed in porcelain crucibles, and ignited to $\mathrm{ZrO}_{2}$.

The results are given in table 8 . 
TABLE 8. Recovery of zirconium by precipitation with cup ferron in a solution containing ethylenediaminetetraacetic acid

\begin{tabular}{c|c|c|c}
\hline & \multicolumn{3}{|c}{ Zirconium dioxide } \\
$\begin{array}{c}\text { Experi- } \\
\text { ment }\end{array}$ & Added & Found & Error \\
\cline { 2 - 3 } & & & \\
\hline & $m g$ & $m g$ & $m g$ \\
& 0.6 & 0.6 & 0.0 \\
1 & 10.3 & 10.3 & .0 \\
3 & 25.2 & 25.1 & -.1 \\
$4 \ldots$ & 55.2 & +.1 \\
\hline
\end{tabular}

The filtrates obtained according to the procedure in section 3.4 were acidified with $50 \mathrm{ml}$ of hydrochloric acid and the zirconium recovered and determined by the above procedure. These results are given in table 7 .

\section{Procedure for Separating Titanium, Zir- conium, Iron, and Aluminum From One Another}

The following procedure is designed for a total quantity of about $0.5 \mathrm{~g}$ of mixed oxides. The maximum amount of each oxide that can be present is: $0.5 \mathrm{~g}$ of $\mathrm{TiO}_{2} ; 0.25 \mathrm{~g}$ of $\mathrm{ZrO}_{2} ; 0.05 \mathrm{~g}$ of $\mathrm{Fe}_{2} \mathrm{O}_{3}$; and $0.05 \mathrm{~g}$ of $\mathrm{Al}_{2} \mathrm{O}_{3}$. The minimum amount of $\mathrm{ZrO}_{2}$, $\mathrm{Fe}_{2} \mathrm{O}_{3}$, and $\mathrm{Al}_{2} \mathrm{O}_{3}$ that can be determined is about $0.0005 \mathrm{~g}$ each. A very accurate determination of these elements requires a knowledge of the approximate composition of the sample.

\subsection{Preparation of the Solution for Analysis}

Synthetic solutions were prepared by mixing weighed portions of each of the four standard solutions so that the above maxima and minima were observed. Each of the synthetic solutions was treated as follows:

Dilute the synthetic solution to about $250 \mathrm{ml}$. To precipitate the metals as their respective quinolates, add $20 \mathrm{ml}$ of acetic acid containing sufficient 8-hydroxyquinoline to provide approximately $1 \mathrm{~g}$ in excess of the amount required to precipitate all four metals. The nominal compositions of the metal quinolates are: $\quad \mathrm{TiO}\left(\mathrm{C}_{9} \mathrm{H}_{6} \mathrm{NO}\right)_{2} ; \quad \mathrm{Zr}\left(\mathrm{C}_{9} \mathrm{H}_{6} \mathrm{NO}\right)_{4}$; $\mathrm{Fe}\left(\mathrm{C}_{9} \mathrm{H}_{6} \mathrm{NO}\right)_{3}$; and $\mathrm{Al}\left(\mathrm{C}_{9} \mathrm{H}_{6} \mathrm{NO}\right)_{3}$.

Neutralize the solution to an acidity of $p \mathrm{H} 5$ by adding diluted ammonium hydroxide $(1+1)$. Wash the electrodes of the $p \mathrm{H}$ meter with water and wipe them with bits of filter paper. Reserve these bits of paper and later add them to the mixed quinolate precipitate.

Digest the solution containing the mixed quinolate precipitate for a few hours on the steam bath and then cool it to room temperature. Filter the solution through a $12.5-\mathrm{cm}$ paper and wash the precipitate and filter with a solution of water that has been saturated with 8-hydroxyquinoline.

Dissolve the mixed quinolates of titanium zirconıum, iron, and aluminum in the following manner. Place the filter and precipitate in the beaker in which the precipitation was made and add $100 \mathrm{ml}$ of a 10 percent solution of citric acid in diluted hydrochloric acid $(5+95)$ and digest on the steam bath until solution of the precipitate is effected. Break up the filter paper by stirring the solution. Filter the solution through an $11-\mathrm{cm}$ paper and wash the filter with a hot $\left(70{ }^{\circ} \mathrm{C}\right) 2$-percent solution of citric acid in diluted hydrochloric acid $(1+99)$. Next, wash it with a hot $\left(70^{\circ} \mathrm{C}\right)$ solution of ammonium citrate, prepared by dissolving $10 \mathrm{~g}$ of citric acid in $400 \mathrm{ml}$ of water, adjusting the alkalinity to between $p \mathrm{H} 8.5$ and 9.0 with ammonium hydroxide, and finally diluting to a volume of $500 \mathrm{ml} .^{6}$

\subsection{Separation of Iron From Titanium, Zirconium, and Aluminum and its Subsequent Determination}

Evaporate the solution obtained as described above to about $150 \mathrm{ml}$. Add $10 \mathrm{ml}$ of hydrochloric acid and adjust the acidity of the solution to $p \mathrm{H} 1.5$ with diluted ammonium hydroxide $(1+3)$. Digest the solution on a steam bath for one-half hour. Add enough ethanol so that the final solution will contain $75 \mathrm{ml}$ of ethanol after the addition of the 1-nitroso-2naphthol reagent solution which contains 50 percent of ethanol by volume. Slowly add the 1-nitroso-2naphthol reagent solution to the warm solution until the approximate amount necessary to precipitate the iron as $\mathrm{Fe}\left(\mathrm{C}_{10} \mathrm{H}_{6} \mathrm{O}_{2} \mathrm{~N}\right)_{3}$ has been added and/allow the solution to stand at room temperature for one-half hour. Determine the $p \mathrm{H}$ of the solution and adjust, if necessary, to $p \mathrm{H} 1.5$ with diluted hydrochloric acid $(1+9)$. Add enough 1-nitroso-2-naphthol solution to produce a $0.2-\mathrm{g}$ excess of the reagent and allow the solution to stand overnight. Filter the solution through a $9-\mathrm{cm}$ paper and thoroughly wash the precipitate and filter with a warm $\left(60^{\circ} \mathrm{C}\right)$ solution of ammonium citrate. The wash solution is prepared by dissolving $10 \mathrm{~g}$ of citric acid in $400 \mathrm{ml}$ of water, adjusting the acidity to $p \mathrm{H} 4.5$ with ammonium hydroxide, and diluting to $500 \mathrm{ml}$.

Decompose the precipitate and filter in a porcelain crucible by heat from an infrared lamp. Complete the ignition at $900{ }^{\circ} \mathrm{C}$ in an electric furnace, and weigh the residue as $\mathrm{Fe}_{2} \mathrm{O}_{3}$.

\subsection{Separation of Titanium and Zirconium From Aluminum}

Add $50 \mathrm{ml}$ of hydrochloric acid to the filtrate obtained in the separation of iron by 1-nitroso-2naphthol. Evaporate the solution to about $200 \mathrm{ml}$ on a steam bath to free it of ethanol. Cool the resulting solution to about $60{ }^{\circ} \mathrm{C}$ and slowly add enough cupferron reagent solution to precipitate only about 90 percent of the titanium and zirconium. Digest the solution at this temperature and stir the solution until the precipitate changes from a bulky, flocculent form to one of dense compact nature. Then, slowly add cupferron reagent solution until a permanent precipitate no longer forms. Cool

\footnotetext{
${ }^{6}$ When filters were ignited after the above treatment, no residue was found.
} 
the solution to room temperature and add $10 \mathrm{ml}$ more of the cupferron reagent solution. Allow the solution to stand about $4 \mathrm{hr}$ in a refrigerator. Catch the precipitate on a $12.5-\mathrm{cm}$ paper, and wash it with a 0.1 -percent solution of cupferron in diluted hydrochloric acid $(1+9)$.

Reserve the filtrate for the determination of aluminum as described in section 4.4. Reserve the precipitate for the separation of titanium from zirconium as described in section 4.5.

\subsection{Recovery and Determination of Aluminum}

Cool the filtrate obtained in the separation of titanium and zirconium from aluminum (section $4.3)$ in an ice-bath and neutralize it to $p \mathrm{H} 4.0$ with diluted ammonium hydroxide $(1+1)$. Add $20 \mathrm{ml}$ of the cupferron reagent solution and allow the solution to stand overnight in a refrigerator. Catch the precipitate on a $12.5-\mathrm{cm}$ paper and wash it with a 1-percent aqueous solution of cupferron. Place the filter and precipitate in a porcelain crucible and decompose them by heating with an infrared lamp. Complete the ignition in an electric furnace at $1,100^{\circ} \mathrm{C}$. and weigh the residue as $\mathrm{Al}_{2} \mathrm{O}_{3}$.

\subsection{Separation of Titanium From Zirconium and its Subsequent Determination}

Place the precipitate of titanium and zirconium cupferrates obtained in section 4.3 in a $150-\mathrm{ml}$ beaker and decompose it and the filter with heat from an infrared lamp. Then place the beaker and its contents in an electric furnace and raise the temperature to $450{ }^{\circ} \mathrm{C}$. Heat them at this temperature overnight or until carbon is no longer visible. Do not heat above $450{ }^{\circ} \mathrm{C}$ because the oxides so formed are difficultly soluble in sulfuric acid. Allow the beaker and its contents to cool to room temperature.

To the beaker containing the mixed titanium and zirconium oxides, add $30 \mathrm{ml}$ of diluted sulfuric acid $(1+1)$. Place the covered beaker on an electric hot plate and dissolve the oxides by heating at a medium heat. Cool the solution, dilute it to $100 \mathrm{ml}$ with water, and filter it through a 9 -cm paper, to free the solution of dehydrated silica and to retain any undissolved oxides. To determine the amount of undissolved oxides, wash the paper with diluted sulfuric acid $(1+9)$ and ignite it in a platinum crucible. Treat the ash with $2 \mathrm{ml}$ of hydrofluoric acid and 2 drops of sulfuric acid and heat to volatilize any silica present as silicon tetrafluoride. Ignite the crucible again and weigh any residue as $\mathrm{TiO}_{2}{ }^{7}$ If significant, this amount should be added to that determined later.

Add enough solid ethylenediaminetetraacetic acid to the solution to give an excess of $0.5 \mathrm{~g}$ over the

7 The residue in most cases was found to be less than $0.1 \mathrm{mg}$. In those cases $\mathrm{n}$ which it exceeded $0.1 \mathrm{mg}$, it was found to be $\mathrm{TiO}_{2}$. approximate amount required to complex the zirconium. Then add enough solid 8-hydroxyquinoline to the solution to give an excess of $1 \mathrm{~g}$ over the amount required to precipitate the titanium. Zirconium forms a one-to-one molar complex with ethylenediaminetetraacetic acid, and one mole of titanyl ion is precipitated by two moles of 8-hydroxyquinoline. Heat the solution on the steam bath until the solid ethylenediaminetetraacetic acid and solid 8-hydroxyquinoline are dissolved. Neutralize the clear solution to $p \mathrm{H} 1.0$ with diluted ammonium hydroxide $(1+1)$ and allow it to stand for $30 \mathrm{~min}$. Dilute it to about $450 \mathrm{ml}$ and add $1-\mathrm{ml}$ portions of the ammonium acetate reagent solution until a permanent precipitate forms or an acidity of $p \mathrm{H} 2.0$ is obtained, whichever occurs first. Heat the solution on the steam bath until the precipitate settles. Add four $5-\mathrm{ml}$ portions of the ammonium acetate reagent solution at 10-minute intervals. Next heat the solution for about 1 hour longer and then cool it to room temperature. Adjust the acidity of the solution to $p \mathrm{H} 4.5$ with the ammonium acetate reagent solution. Heat the solution on the steam bath overnight, cool it in an ice bath for $4 \mathrm{hr}$, and filter it through a $12.5-\mathrm{cm}$ paper. Wash the precipitate and filter with a solution prepared by dissolving $1 \mathrm{~g}$ of 8-hydroxyquinoline in $15 \mathrm{ml}$ of acetic acid, diluting it to $400 \mathrm{ml}$, adding $0.5 \mathrm{~g}$ of ethylenediaminetetraacetic acid, neutralizing the solution to $p H 4.5$ with diluted ammonium hydroxide $(1+1)$, and finally diluting to a volume of $500 \mathrm{ml}$.

Place the precipitate and filter in a porcelain crucible. Decompose the precipitate and filter by heating with an infrared lamp. Ignite the residue in an electric furnace at $1,000{ }^{\circ} \mathrm{C}$, and weigh it as $\mathrm{TiO}_{2}$.

\subsection{Recovery and Determination of Zirconium}

To the filtrate reserved from section 4.5 , add 50 $\mathrm{ml}$ of hydrochloric acid. Add a sufficient quantity of cupferron reagent solution to precipitate the zirconium and to provide an excess of about $1 \mathrm{~g}$ of cupferron. It requires 4 moles of cupferron to precipitate 1 mole of zirconium. Allow the solution and precipitate to stand in a refrigerator overnight. Catch the precipitate on a $12.5-\mathrm{cm}$ paper and wash it with a 0.2 -percent solution of cupferron in diluted hydrochloric acid $(1+19)$. Decompose the precipitate and filter in a porcelain crucible by heat from an infrared lamp. Complete the ignition in an electric furnace at $1,000{ }^{\circ} \mathrm{C}$ and weigh the residue as $\mathrm{ZrO}_{2}$.

\section{Results}

The results obtained when the foregoing procedure was applied to the analysis of synthetic mixtures of titanium, zirconium, iron, and aluminum are given in table 9. 
TABLE 9.-Results obtained in the separation of titanium, zirconium, iron, and aluminum from one another

\begin{tabular}{|c|c|c|c|c|c|c|c|c|c|c|c|c|}
\hline \multirow{2}{*}{ Experiment } & \multicolumn{3}{|c|}{ Titanium dioxide } & \multicolumn{3}{|c|}{ Zirconium dioxide } & \multicolumn{3}{|c|}{ Ferric oxide } & \multicolumn{3}{|c|}{ Aluminum oxide } \\
\hline & Added & Found & Error & Added & Found & Error & Added & Found & Error & Added & Found & Error \\
\hline & $q$ & $a$ & $m g$ & $g$ & $g$ & $m g$ & $g$ & $g$ & $m g$ & $g$ & $g$ & $m g$ \\
\hline $\begin{array}{l}1 \\
2 \\
3 \\
4 \\
5 \\
6 \\
7 \\
8\end{array}$ & $\begin{array}{l}0.4964 \\
.4980 \\
.4269 \\
.3476 \\
.3422 \\
.3210 \\
.2829 \\
.2323\end{array}$ & $\begin{array}{r}0.4962 \\
.4979 \\
.4269 \\
.3477 \\
.3424 \\
.3208 \\
.2832 \\
.2326\end{array}$ & $\begin{array}{r}-0.2 \\
-.1 \\
.0 \\
+.1 \\
+.2 \\
-.2 \\
+.3 \\
+.3\end{array}$ & $\begin{array}{r}0.0006 \\
.0102 \\
.0244 \\
.0544 \\
.1028 \\
.1530 \\
.2064 \\
.2511\end{array}$ & $\begin{array}{l}0.0007 \\
.0102 \\
.0245 \\
.0543 \\
.1027 \\
.1528 \\
.2062 \\
.2510\end{array}$ & $\begin{array}{r}+0.1 \\
.0 \\
+.1 \\
-.1 \\
-.1 \\
-.2 \\
-.2 \\
-.1\end{array}$ & $\begin{array}{r}0.0005 \\
.0051 \\
.0209 \\
.0479 \\
.0124 \\
.0055 \\
.0105 \\
.0054\end{array}$ & $\begin{array}{l}0.0006 \\
.0051 \\
.0210 \\
.0480 \\
.0122 \\
.0054 \\
.0105 \\
.0055\end{array}$ & $\begin{array}{r}+0.1 \\
.0 \\
+.1 \\
+.1 \\
-.2 \\
-.1 \\
.0 \\
+.1\end{array}$ & $\begin{array}{l}0.0005 \\
.0047 \\
.0226 \\
.0522 \\
.0050 \\
.0097 \\
.0048 \\
.0092\end{array}$ & $\begin{array}{l}0.0007 \\
.0048 \\
.0228 \\
.0520 \\
.0051 \\
.0100 \\
.0049 \\
.0090\end{array}$ & $\begin{array}{l}+0.2 \\
+.1 \\
+.2 \\
+.2 \\
+.1 \\
+.3 \\
+.1 \\
-.2\end{array}$ \\
\hline
\end{tabular}

\section{References}

[1] W. S. Clabaugh, R. T. Leslie, and R. Gilchrist, J. Research NBS $\mathbf{5 5}, 261$ (1955) RP2628.

[2] W. S. Clabaugh and R. Gilchrist, J. Am. Chem. Soc. $\boldsymbol{4 4}$, 2104 (1952).

[3] K. Tanii, H. Hosimiya, T. Ikeda, J. Chem. Soc., Japan 61, $269(1940)$.

[4] A. Jolles, Z. anal. Chem. 36, 149 (1897).

[5] Gantois, Lejeune, Noel, and Scohy, Bull. soc. chim., Belg. 43, 545 (1934).

[6] J. F. Flagg, Organic Reagents, p. 207 (Interscience Publishers, New York, N.Y., 1948).

[7] J. Brown, J. Am. Chem. Soc. 39, 2358 (1917).

[8] I. Bellucei and L. Grassi, Gazz. chim. ital. 43, I, 570 (1913)
[9] K. Schroeder, Z. anorg. Chem. \%2, 89 (1911).

[10] A. Pinkus and E. Belche, Bull. soc. chim. Belg. 36, 277 (1927)

[11] J. S. Fritz and M. O. Fulda, Anal. Chem. 26, 1206. (1954).

[12] R. L. Pecsok and E. F. Maverick, J. Am. Chem. Soc. 76, 358 (1954).

[13] R. M. Sen Sarma and A. K. Mallik, Anal. chim. Acta 12, $329(1955)$

[14] R. Berg and M. Teitelbaum, Z. anal. Chem. 81, 1 (1930).

[15] J. Arend and H. Schnellenbach, Arch. Eisenhüttenw. 4, $265(1930)$

[16] A. K. Majumdar and J. B. R. Chowdhury, Anal. chim. Acta 15, 105 (1956).

(Paper 64A6-79) 


\section{Publications of the National Bureau of Standards}

\section{Selected Abstracts}

Error analysis of a standard microwave phase shifter, G. E. Schafer and R. W. Beatty, J. Research NBS 64C, No. 4, 261 (1960).

A standard microwave phase shifter has been proposed which utilizes an adjustable short circuit attached to a tunable three-arm waveguide junction. Two classes of errors considered are those due to imperfect tuning of the waveguide junction and those due to inaccuracies in determining the motion of the adjustable short circuit and the width of the waveguide, termed tuning and dimensional errors, respectively. Graphs are presented for estimating the scattering coefficient magnitudes needed to estimate limits of tuning error from observations of amplitude changes during the tuning procedure. Graphs are presented for estimating limits of dimensional error for WR-90 waveguide in the recommended frequency range of 8.2 to $12.4 \mathrm{kMc} / \mathrm{s}$ from tolerances of the axial motion of the short circuit and broad dimension of the waveguide.

$\mathrm{X}$-ray attenuation coefficients from 13 to $80 \mathrm{Mev}$ for hydrogen, carbon, water, and aluminum, J. M. Wyckoff and H. W. Koch, Phys. Rev. 11\%, No. 5, $1261(1960)$.

The X-ray attenuation coefficients for hydrogen, carbon, water, and aluminum have been measured in the energy range from 13 to $80 \mathrm{Mev}$ by placing varying lengths of attenuators in a $90 \mathrm{Mev}$ bremsstrahlung beam in a good geometry experiment using a large sodium-iodide total-absorption speccrometer as the detector. In the hydrogen case, a difference method employing cyclohexane $\left(\mathrm{C}_{6} \mathrm{H}_{12}\right)$ and graphite was used. The theoretical attenuation coefficients were calculated using selected Compton and triplet cross sections in addition to the small quasi-deuteron cross sections. A pair cross section increase of $2.25 \%$ was required for carbon, water and aluminum to bring the total calculated coefficients into agreement with the measured coefficients in the $60 \mathrm{Mev}$ region. The difference between these calculated cross sections and the measured cross sections in the 13 to $50 \mathrm{Mev}$ region has been ascribed to the giant resonance nuclear absorption. A larger high energy tail to this absorption than predicted by $(\gamma, p)$ and $(\gamma, \mathrm{n})$ experiments is indicated.

Forced mixing in boundary layers, G. B. Schubauer and W. G. Spangenberg, J. Fluid Mech. 8, No. 1, 10 (1960).

The effect of increasing the rate of mixing in turbulent boundary layers in a region of adverse pressure gradient has been investigated experimentally. Only the two-dimensional case was considered. The boundary layer was formed on a flat wall in a special wind tunnel in which a variety of adverse pressure gradients could be obtained. Speeds were low enough to neglect compressibility. The main objective was to compare the effect of increasing the rate of mixing with the effect of reducing the pressure gradient on boundary-layer development and separation. A variety of mixing schemes was tried, all of them involving fixed devices arranged in a row on the surface in the region of rising pressure. While these differed considerably in effectiveness, they had a generally similar effect on the flow; and, except for effects arising from changes in displacement and momentum thickness introduced at the devices, their effect on the layer was basically equivalent to that of a decrease in pressure gradient. Apart from forced mixing, the shape of the pressure distribution was found to have a significant effect on displacement and momentum thickness, these being minimized and the wall distance decreased for a given pressure rise by a distribution with an initially steep and progressively decreasing gradient.

Flow and stress near an interface between stratified liquids, K. Lofquist, Phys. of Fluids 3, No. 2, 158 (1960).

Observations are made of a density current system in which salt water flows turbulently under a pool of fresh water. The density and rate of flow of the salt water are varied, resulting in varying degrees of agitation of the interface. Measurements include the interface slope, the velocity and density profiles and the rate of mixing. Profiles of stress and effective viscosity are developed from the observations and the equation of motion. In the zone of stable stratification the effective viscosity has a minimum equal to or greater than the molecular viscosity depending upon whether the interface is laminar or agitated. Dimensionless relationships between the observed or computed quantities and the given fluid properties and flow characteristics are investigated. The principal independent variables are a Reynolds number and a Froude number. An interfacial stress coefficient is found to depend upon both. With fair accuracy, the velocity profile can be related to the interfacial stress in a manner analogous to that for turbulent flow near a rigid boundary.

Kinetics of the transport of water through silicate glasses at ambient temperatures, W. Haller, Phys. Chem. of Glass 1, 46 (1960).

The phenomenology of the transport of water constituents into the network of silicate glasses at ambient temperatures is discussed. The geologic hydration of obsidian, the hydration of obsidian artifacts, the water vapor sorption of a high surface area alumino silicate glass, and the water vapor sorption of vitreous silica are compared. It is concluded that, in spite of a wide variety of glass compositions and experimental conditions, the sorption rates are of the order of $10^{-8}$ g. $\mathrm{cm}^{-2} \cdot \mathrm{day}^{-1 / 2}$. The sorption mechanism is interpreted as diffusion of water into the glass, accompanied by an irreversible change in the glass structure.

Heated cell for quantitative infrared spectrophotometry, F. J. Linnig and J. E. Stewart, Anal. Chem. 32, 891 (1960).

A heated cell is described which is useful for quantitative infrared spectrophotometry. It has been employed for making quantitative measurements on mixtures that are homogeneous only at elevated temperatures. It may be used for obtaining spectra of highly viscous materials and of materials above their melting points, and for quantitatively following chemical reactions at elevated temperatures.

Calibration for carrier operated microphones and other reversible transducers, M. D. Burkhard, E. L. R. Corliss, W. Koidan, and F. Biagi, J. Acoustical Soc. Am. 32, No. 4, 501 (1960).

An insert technique described in this paper makes it possible to carry out sound pressure measurements using a microphone operated in a carrier circuit with almost the same accuracy 
as can be achieved with more conventional preamplifiers. The carrier system is modified to include a microphone polarizing voltage if the transducer is not self-polarized. Then a calibrating audio-frequency voltage is used to drive the transducer diaphragm to the same displacement amplitude as that generated by the sound pressure. Instead of matching the open-circuit voltage of the microphone, diaphragm motion is matched. A displacement response constant, independent of frequency, is used to determine sound pressure, in contrast to the usual open-circuit response, which depends on frequency.

In a manner analogous to the determination of open-circuit pressure response by the reciprocity technique, the acoustic admittance of the microphone may be evaluated from a series of three voltage ratio measurements and the calculated acoustical transfer admittance of a calibrating coupler. This result can be combined with the open-circuit pressure response determined by the reciprocity technique to give an explicit evaluation of the electromechanical coupling constant.

Accurate microwave wavemeters with convenient calibration tables, H. E. Bussey and A. J. Estin, Rev. Sci. Instr. 31, 410 (1960).

Accurate and convenient microwave cavity wavemeters are described that are suitable for many precise physical mesaurements. High Q's were attained by refined construction techniques. At $9000 \mathrm{Mc}$ a precision of $0.02 \mathrm{Mc}$ was obtained. The absolute accuracy also may be very high after strains in the metal have stabilized. A calibration table containing $10^{4}$ entries, easily formed by means of a high speed computer, makes the wavemeters convenient to use. The curve fitting method, accurate to one in $10^{\circ}$, is described.

The nova outburst. V. The temperature and radius of the central exciting star and observation of elements other than hydrogen, S. Pottasch, Ann. Astrophys J. 22, No. 4, 412 (1959).

The temperature and radius of the central star (the actual nova) is determined for six novae over the period beginning somewhat after maximum and extending until the nova shell is optically thin to hydrogen ioniozing radiation. During this period the temperature is found to remain roughly constant while the radius appears to decrease. The temperatures are determined using a variation of Z Z ANSTRA's method. The results are shown in Table 2 . The energies emitted by stars with these temperatures and radii are computed for the period until the shell becomes optically thin to $H$ ionizing radiation and these energies are compared to the energy found from the light curve and the kinetic energies of the shell.

The extent of the ionized region of the shell can be computed knowing the temperature and radius of the exciting star. This is done and compared with the extent obtained in a different manner in a previous analysis.

Finally the composition of the shell is discussed. For five novae the amounts of hydrogen, helium, oxygen, nitrogen, sulfer, calcium, and neon are determined. The abundance of the last five elements appears to be greater, by a factor of about 5, than the generally accepted cosmic abundance.

Guiding of electromagnetic waves by uniformly rough surfaces - Part I, J. R. Wait, IRE Trans. Ant. Prop. AP-y, S-154 (1959).

A simple derivation is given for the reflection of electromagnetic waves from a perfectly conducting plane surface which has a uniform distribution of hemispherical bosses whose electrical constants are arbitrary. The spacing between the centers of the bosses is taken to be small which is the justification for neglecting the incoherent radiation. An approximate boundary condition is developed which must be satisfied in an average sense by the tangential fields on the reference plane.

The excitation of surface waves on the rough surface is then discussed. It is indicated that to a first order, a rough surface of the kind described here possesses an inductive surface reactance and will support a trapped wave. The effect cf finite conductivity of the bosses is to exponentially damp this trapped wave.

Guiding of electromagnetic waves by uniformly rough surfaces - Part II, J. R. Wait, IRE Trans. Ant. Prop. AP-y, S-163 (1959).

Using the model of a single rough surface described in Part I, the influence of curvature is considered. The starting point is a residue-series solution for a vertical dipole over a sphere with an arbitrary surface impedance. It is shown that the curvature has a profound influence on the nature of the surface wave, although it uniformly approaches the conditions for a plane boundary as the radius of curvature approaches infinity.

The propagation between the space bounded by two parallel uniformly rough surfaces is also considered. This is treated first for plane boundaries and then for concentric spherical boundaries. The latter model is useful in explaining certain experimental data on the terrestrial propagation of VLF radio waves.

\section{Normal modes of a lattice of oscillators with many resonances and dipolar coupling, U. Fano, Phys. Rev.} 118, No. 2, 451 (1960).

The normal modes of a lattice of coupled dipoles are studied as a model of the collective excitations of electrons in condensed materials. Two types of oscillations are found, in which electrostatic coupling has a dominant influence. One of them is analogous to the oscillation of an electron plasma and has a high dipole moment. Other collective oscillations have a low net dipole moment, owing to destructive interference between out-of-phase components. These two types of oscillation occur in systems with a sufficiently high density of oscillator strength in space and in spectrum. A simple estimate indicates that most condensed materials fulfill this condition.

\section{Electron detachment from the negative hydrogen ion by electron impact, S. Geltman, Proc. Phys. Soc. (London, England) LXXV, p. 67 (1960).}

The Born-Oppenheimer approximation has been used to evaluate the cross section for the detachment of electrons from $\mathrm{H}^{-}$by electron impact over an energy range from threshold $(0.76 \mathrm{ev})$ to $75 \mathrm{ev}$. An empirical correction was then applied to account approximately for the long range Coulomb repulsion between the incident electron and the negative ion. The resulting cross section has a broad maximum of $700 \pi a_{0}{ }^{2}$ centered at about $45 \mathrm{ev}$.

Spectra emitted from rare gas-oxygen solids during electron bombardment, L. J. Schoen and H. P. Broida, J. Chem. Phys. 32, No. 4, 1184 (1960)

Light emission from rare gas solids containing small amounts of oxygen has been excited by an electron bombardment technique. The Herzberg bands of neutral oxygen and a line group believed to be the ${ }^{1} \mathrm{~S} \rightarrow{ }^{1} \mathrm{D}$ transition of oxygen atoms from the strongest features of the observed spectra. In a neon matrix, the Second Negative system of $\mathrm{O}_{2}+$ has been identified. The effect of the various solids on the vibrational structure of the Herzberg bands is discussed.

Detection and estimation of low concentrations of aldehyde in air, E. E. Hughes and S. G. Lias, Anal. Chem. 32, No. 6, 708 (1960).

Aldehyde is adsorbed from an air stream on purified silica gel. The gel is then treated with a solution of p-phenylene diamine and hydrogen peroxide. Oxidation of the p-phenylene diamine is catalyzed by aldehydes and the depth of color produced on the gel by the oxidation products is a measure of the quantity of aldehyde adsorbed. The method is 
simple and little equipment is involved. Quantities as low as $10^{-8}$ mole percent can be easily detected. The method can be readily adapted for field use.

Nonresonant absorption in symmetric-top gases: Dependence of relaxation frequency on temperature, A. A. Maryott, A. Estin, and G. Birnbaum, J. Chem. Phys. 3\%, No. 5, 1501 (1960).

The nonresonant absorption spectra of $\mathrm{CHF}_{3}, \mathrm{CH}_{3} \mathrm{~F}$, and $\mathrm{CClF}_{3}$ were obtained in the gaseous state at various temperatures in the range $230^{\circ}$ to $360^{\circ} \mathrm{K}$. In all cases the maximum value of the dielectric loss per unit pressure varies as $\mathrm{T}^{-2}$, in accordance with the Debye equation. The variation of relaxation frequency (line width) with pressure and temperature is represented by $\Delta \mu \propto \mathrm{p} \mathrm{T}^{-\mathrm{m}}$, where $\mathrm{m}$ has the following values: $1.59 \pm 0.03$ for $\mathrm{CHF}_{3}, \quad 1.60 \pm 0.02$ for $\mathrm{CH}_{3} \mathrm{~F}$, and $1.27 \pm 0.02$ for $\mathrm{CClF}_{3}$. Since $\mathrm{CHF}_{3}$ and $\mathrm{CH}_{3} \mathrm{~F}$ have rather large dipole moments, the predominant interaction should be of the first-order dipole-dipole type. On this basis Anderson's theory predicts $m=1$. Closer agreement with the experimental data is obtained with an expression derived essentially from dimensional considerations of a torqueimpulse model, which gives $\mathrm{m}=1.5$. In the case of $\mathrm{CClF}_{3}$, which has a comparatively small dipole moment, the data indicate that molecular reorientation is governed primarily by forces of shorter range.

Electron impact study of the cyanogen halides, J. T. Herron and V. H. Dibeler, J. Am. Chem. Soc. 8\%, 1555 (1960).

Mass spectra and appearance potentials are reported for the principal ions of cyanogen chloride, bromide, and iodide. Using these data, the following thermochemical values have been computed: $\triangle \mathrm{H}_{\mathrm{f}} \mathrm{CN}=89 \pm 2 \mathrm{kcal} / \mathrm{mole} ; \triangle \mathrm{H}_{\mathrm{f}} \mathrm{CN}^{-}=15 \pm 4$ $\mathrm{kcal} / \mathrm{mole}$, E.A. $(\mathrm{CN})=74 \pm 4 \mathrm{kcal} / \mathrm{mole}$.

The structure of $\mathrm{O}, \mathrm{O}^{\prime}$-diethyl methylphosphonothioate and conjugative properties of the $\mathrm{P}=\mathrm{S}$ bond, H. Finegold, J. Am. Chem. Soc. 82, No. 10, 2641 (1960).

The structure of $\mathrm{O}$, O-diethyl methylphosphonothioate: $\mathrm{CH}_{3} \mathrm{P}(\mathrm{S})\left(\mathrm{OCH}_{2} \mathrm{CH}_{3}\right)_{2}$, is shown to include two non-equivalent ethoxy groups. The conclusion was reached by a study of the hyperfine nuclear resonance spectrum resulting from both the $\mathrm{H}^{1}$ and $\mathrm{P}^{31}$ spin resonance transitions. A theory of resonance (mesomeric) stabilization of the molecule involving the $\mathbf{P}=\mathrm{S}$ bond is proposed to explain the observations. An important inference is that the compound is asymmetric and would be expected to show optical activity.

Analysis of methyl methacrylate copolymers by gas chromatography, J. Strassburger, G. M. Brauer, M. Tryon, and A. F. Forziati, Anal. Chem. 32, No. 4, $454(1960)$.

Detection, identification, and quantitative determination of copolymers of methyl methacrylate was accomplished by gas chromatographic analysis of the pyrolysis products. The procedure distinguishes between polymer mixtures and copolymers, and detects the presence of $0.2 \%$ of copolymer. Composition can be determined quantitatively with a precision of $\pm 0.5 \%$, from standard curves of the ratio of peak areas at known composition. The analysis takes only a few minutes, can be readily adapted to other copolymers, and is especially useful for cross-linked, insoluble materials.

The black void reactor concept, C. O. Muehlhause, Nuclear Sci. and Engr. \%, No. 6, 505 (1960).

The application of heavily loaded cylindrical fuel elements to two principal reactor configurations is considered. The objective of the work is the design of research reactors suitable for radiation effects studies.
The Stokes flow problem for a class of axially symmetric bodies, L. E. Payne and W. H. Pell, J. Fluid Mech. 8, Pt. 4, 529 (1960).

This is a continuation of earlier work by the same authors. The methods of the generalized axially symmetric potential theory of A. Weinstein and certain representation theorems of L. Payne for the solution of repeated operator equations are applied to the solution of the Stokes (slow) flow about a spindle-shaped body. The stream function of the flow is found and an expression is given for the drag of the body.

Elastic constants of synthetic single crystal corundum at room temperature, J. B. Wachtman, W. E. Tefft, D. G. Lam, R. P. Stinchfield, J. Am. Ceram. Soc. 43, No. 6, 334 (1960).

The six elastic constants (and six elastic compliances) of corundum were determined in the kilocycle/sec frequency range by an accurate, resonance method. The results were checked in the megacycle/sec range with a less accurate, pulse velocity method. The elastic moduli for polycrystalline alumina calculated from the single crystal compliances determined by the resonance method are in good agreement with experimental values obtained on high density polycrystalline alumina. The variation of Young's modulus and of the shear modulus with orientation was calculated from the compliances and the results are shown graphically. The results of the present work do not agree well with previous work on single crystal sapphire. The specification of orientation and the theory used to calculate the elastic constants are given in detail to support the contention that the results of the present work are correct.

Dewar system for low temperature experiments, C. T. Zahn, Rev. Sci. Instr. 31, No. 3, 328 (1960).

A special system of glass Dewars for experiments at low temperatures is described in which the liquid nitrogen shield consists of two separate parts, one dipping into the other. The upper shield is constructed with three walls rather than the usual two, since it is open at the bottom. The extra inner wall serves to prevent the liquid nitrogen from flowing through the open bottom. The liquid helium Dewar fits fairly closely inside this extra wall, with a thin air-space between the two, and extends downward into the lower shield. The upper shield is thus mechanically isolated from the liquid helium Dewar. Access to a cold spot of the liquid helium flask is provided by a tube passing upward through the bottom of the lower shield and coupled to the liquid helium flask by means of a spherical ground-glass joint. Various advantages of this system and possible modifications thereof are discussed.

The ionization potential of fluorine, J. T. Herron and V. H. Dibeler, J. Chem. Phys. 32, No. 6, 1885 (1960).

The ionization potential of fluorine was found to be $15.83 \mathrm{ev}$ as measured by electron impact. Values for the ionization potentials of $\mathrm{Cl}_{2}, \mathrm{Br}_{2}$, and the second ionization potentials of $\mathrm{Cl}_{2}$ and $\mathrm{Br}_{2}$ are also reported.

Heat of formation of nitrogen trifluoride and the N-F bond energy, G. T. Armstrong, S. Marantz, and C. F. Coyle, Commun. to Editor, J. Am. Chem. Soc. 81, 3798 (1959).

By igniting mixtures of $\mathrm{NF}_{3}$ with hydrogen over water and of $\mathrm{NF}_{3}$ with ammonia, the heats of the following reactions were determined in a bomb calorimeter

$$
\begin{aligned}
\mathrm{NF}_{3}(\mathrm{~g})+\frac{3}{2} \mathrm{H}_{2}(\mathrm{~g})=\frac{1}{2} \mathrm{~N}_{2}(\mathrm{~g})+3 \mathrm{HF}(\mathrm{aq}, \mathrm{a}=1) \\
\Delta \mathrm{H}_{25}=-859.0 \pm 13.4 \mathrm{kj} / \mathrm{mole} \\
=-205.3 \pm 3.2 \mathrm{kcal} / \mathrm{mole}
\end{aligned}
$$

$\mathrm{NF}_{3}(\mathrm{~g})+4 \mathrm{NH}_{3}(\mathrm{~g})=3 \mathrm{NH}_{4} \mathrm{~F}(\mathrm{c})+\mathrm{N}_{\mathrm{z}}(\mathrm{g})$

$$
\Delta \mathrm{H}_{25}=-1085.7 \pm 4.2 \mathrm{kj} / \mathrm{mole}
$$
$259.5 \pm 1.0 \mathrm{kcal} / \mathrm{mole}$ 
The weighted mean heat of formation of $\mathrm{NF}_{3}$ calculated from the above measurements is $-29.7 \pm 1.8 \mathrm{kcal} / \mathrm{mole}$ and the mean $\mathrm{N}-\mathrm{F}$ bond energy is $66.4 \pm 0.8 \mathrm{kcal} / \mathrm{mole}$.

Microwave spectrum and internal rotation of ethyl cyanide, V. W. Laurie, J. Chem. Phys. 31, No. 6, 1500 (1959).

The microwave spectrum of ethyl cyanide has been studied in the region from $17-36 \mathrm{kMc}$. Both parallel and perpendicular transitions have been assigned. Rotational constants (Me) for the ground vibrational state are $a_{0}=27663.30$, $b_{0}=4714.14, c_{0}=4235.14, D_{J}=0.0035, D_{J K}=-0.0496$. From Stark effects the dipole moment is calculated to be $\mu_{\mathrm{a}}=3.78 \mathrm{D}$, $\mu_{\mathrm{b}}=1.38 \mathrm{D}, \mu=4.02 \mathrm{D}$. Hyperfine splittings lead to a value of $-3.3 \mathrm{Mc}$ for the quadrupole coupling of the $\mathrm{N}^{14}$ nucleus along the a-axis. Rotational transitions of molecules in several excited vibrational states have also been measured. A Coriolis interaction between the torsional mode and the in-plane CCN bend has been found and is discussed. Splittings of transitions of molecules in the first excited torsional state show that the barrier hindering internal rotation of the methyl group is $3.05 \mathrm{kcal} / \mathrm{mole}$.

Microwave spectrum of trans-crotononitrile, V. W. Laurie, J. Chem. Phys. 32, No. 5, 1588 (1960).

The microwave spectrum of trans $-\mathrm{H}_{3} \mathrm{CCH}=\mathrm{CHON}$ has been investigated in the region from $13-36 \mathrm{kMc}$. A number of parallel transitions have been measured and fitted with the constants (Mc) $a_{0}=38,2 \times 10^{3}, b_{0}=2297.05, c_{0}=2195.22$, $D_{J}=0.3_{4} \times 10^{-3}, D_{J K}=-12.6 \times 10^{-3}$. Failure to resolve splittings from internal rotation of the methyl group implies a lower limit of $2.1 \mathrm{kcal} / \mathrm{mole}$ for the internal barrier.

Infrared emission spectra of gaseous $\mathrm{B}_{2} \mathrm{O}_{3}$ and $\mathbf{B}_{2} \mathbf{O}_{2}$, D. White, D. E. Mann, P. N. Walsh, and A. Sommer, J. Chem. Phys. 32, No. 2, 481 (1960).

The infrared emission spectra of gaseous $\mathrm{B}_{2} \mathrm{O}_{3}$ and $\mathrm{B}_{2} \mathrm{O}_{2}$ in the temperature range $1400-1800^{\circ} \mathrm{K}$ have been studied in the region 700-4000 $\mathrm{cm}^{-1}$. Distinct bands were found for natural $\mathrm{B}_{2} \mathrm{O}_{3}$ at 2040,1302 and $742 \mathrm{~cm}^{-1}$, and the $\mathrm{B}^{10}-\mathrm{B}^{11}$ isotope shifts measured. From the isotope shift data and other considerations the $\mathrm{B}_{2} \mathrm{O}_{3}$ molecule has been assigned a $V$ structure having $C_{2} \nu$ symmetry. A force constant analysis has been made and a frequency assignment is given from which thermal functions have been computed. The calculated force constants are consistent with the high stability of the molecule. Only one emission band of gaseous $\mathrm{B}_{2} \mathrm{O}_{2}$, at $1890 \mathrm{~cm}^{-1}$, has been observed. A linear $D_{\infty h}$ structure was assumed and a frequency assignment and thermal functions estimated.

Infrared emission spectrum of gaseous $\mathrm{HBO}_{2}$, D. White, D. E. Mann, P. N. Walsh, and A. Sommer, J. Chem. Phys. 32, No. 2, 488 (1960).

The infrared emission spectrum of the vapor phase of the $\mathrm{B}_{2} \mathrm{O}_{3}(\mathrm{l})-\mathrm{H}_{2} \mathrm{O}(\mathrm{g})$ system has been studied at elevated temperatures over the region $700-4000 \mathrm{~cm}^{-1}$. Characteristic bands were found near 3680, 2030, and $1420 \mathrm{~cm}^{-1}$, and approximate $\mathrm{B}^{10}-\mathrm{B}^{11}$ and $\mathrm{H}-\mathrm{D}$ isotope shifts measured. It is shown that these bands arise from the molecule $\mathrm{HBO}_{2}$. The intensity of the $2030 \mathrm{~cm}^{-1}$ band was studied as a function of both temperature and water pressure. The intensity vs temperature measurements lead to a heat of formation, $\Delta H_{0}^{\circ}$, of $-135.0+3 \mathrm{kcal} / \mathrm{mole}$ for $\mathrm{HBO}_{2}(\mathrm{~g})$. The spectroscopic data, considered in the light of our analysis of the $\mathrm{B}_{2} \mathrm{O}_{3}(\mathrm{~g})$ infrared spectrum, are compatible with the structure

$$
\mathrm{O}=\mathrm{B}-\mathrm{O}
$$

H

in which the OBO group is linear and the $\mathrm{H}$ is off-axis. The force constants are found to resemble those determined for $\mathrm{B}_{2} \mathrm{O}_{3}(\mathrm{~g})$. Complete vibrational assignments are given for $\mathrm{HBO}_{2}(\mathrm{~g})$ and its trimer $\left(\mathrm{HBO}_{2}\right)_{3}(\mathrm{~g})$, a species which has recently been shown to exist in this system. Thermal func- tions have been computed for both molecules over a wide temperature range.

A demonstration of color perception with abridged color-projection systems, C. S. McCamy, Photographic Sci. and Engr. 4, No. 3, 155 (1960).

The way primary colors combine to produce colored pictures was demonstrated. The range of colors perceived when less than three primaries were used was attributed to the known psychological effects of induction by contrast, color constancy by discounting of the illuminant, and memory color, all of which were demonstrated. The reproduction characteristics of two-color systems were demonstrated and a direct comparison was made between a two-color and a three-color reproduction of the same scene.

\section{Other NBS Publications}

\section{Journal of Research, Section 64C, No. 4, October- December 1960.75 cents.}

Error analysis of a standard microwave phase shifter. G. E. Schafer and R. W. Beatty. (See above abstract.)

A method of controlling the effect of resistance in the link circuit of the Thomson or Kelvin double bridge. D. Ramaley.

Automatic precise recording of temperature. G. S. Ross and H. D. Dixon.

Gimbal device to minimize the effects of off-center loading on balance pans. H. A. Bowman and L. B. Macurdy.

Response of microchemical balances to changes in relative humidity. H. E. Almer.

Chemical changes occurring during the weathering of two coating-grade asphalts. S. H. Greenfeld.

Characteristics of fifteen coating-grade asphalts. S. H . Greenfeld.

Journal of Research, Section 64D, No. 6, NovemberDecember 1960 . 70 cents.

URSI National Committee Report:

Commission 1. Radio Measurement Methods and Standards.

Commission 2. Tropospheric Radio Propagation.

Commission 3. Ionospheric Radio Propagation.

Commission 4. Radio Noise of Terrestrial Origin.

Commission 5. Radio Astronomy.

Commission 6. Radio Waves and Cireuits

Commission 7. Radio Electronics,

Temperature-induced stresses in solids of elementary shape, L. H. Adams and R. M. Waxler, NBS Mono. 2 (1960) 25 cents.

Table of wavenumbers, $7000 \mathrm{~A}$ to $1000 \mu$, C. D. Coleman, W. R. Bozman, and W. F. Meggers, NBS Mono. 3, Vol. II (1960) $\$ 6.00$.

A method for the dynamic determination of the elastic, dielectric, and piezoelectric constants of quartz, S. A. Basri, NBS Mono. 9 (1960) 15 cents.

The "1958 He ${ }^{4}$ Scale of Temperature," H. Van Dijk, M. Durieux, J. R. Clement, J. K. Logan, and F. G. Brickwedde, NBS Mono. 10 (1960) 20 cents.

Mechanical properties of structural materials at low temperatures - A compilation from the literature, R. M McClintock and H. P. Gibbons, NBS Mono. 13 (1960) $\$ 1.50$.

Vibration-rotation structure in absorption bands for the calibration of spectrometers from 2 to 16 microns, E. K. Plyler, A. Danti, L. R. Blaine, and E. D. Tidwell, NBS Mono. 16 (1960) 20 cents.

New description of thorium spectra, R. Zalubas, NBS Mono. 17 (1960) 65 cents. 
Measurement of neutron flux and spectra for physical and biological applications, NBS Handb. 72 (1960) 35 cents.

Experimental plating of gun bores to retard erosion, V. A Lamb and J. P. Young, NBS Tech. Note 46 (PB151405) (1960) $\$ 2.50$.

Magnetic drum directory and programming system for codesorting letter mail, P. C. Tosini, NBS Tech. Note 50 (PB151409) (1960) \$1.75.

Carrier frequency dependence of the basic transmission loss in tropospheric forward scatter propagation, K. A. Norton, NBS Tech. Note 53 (PB161554) (1960) \$1.00.

Determination of a general index of effort in sorting mail by conventional methods, S. Henig, NBS Tech. Note 54 (PB161555) (1960) 50 cents.

A bibliography of the physical equilibria and related properties of some cryogenic systems, T. M. Flynn, NBS Tech. Note 56 (PB161557) (1960) $\$ 1.75$.

Variable capacitor calibration with an inductive voltage divider bridge, T. L. Zapf, NBS Tech. Note 57 (PB161558) (1960) 50 cents.

A survey and bibliography of recent research in the propagation of VLF radio waves, J. R. Wait, NBS Tech. Note 58 (PB161559) (1960) 75 cents.

Measurements and standards in plasma-physics and astrophysics at the National Bureau of Standards, NBS Tech. Note 59 (PB161560) (1960) \$1.00.

Proceedings of the 1960 conference on the propagation of E.L.F. radio waves (1960), NBS Tech. Note 61 (PB161562) (1960) 75 cents.

The influence of lowered permissible dose levels on atomic energy operations in the United States, L. S. Taylor, Progr. in Nuclear Energy 1, 10 (1960).

Optimum antenna height for ionospheric scatter communication, R. G. Nerril, IRE Trans. on Communs. Systems CS-8, 14 (1960).

Statistical evaluation of interlaboratory cement tests, J. R. Crandall and R. L. Blaine, Am. Soc. Testing Materials Proc. 59, 1129 (1959)

Measured distributions of the instantaneous envelope amplitude and instantaneous frequency of carriers plus thermal and atmospheric noise, A. D. Watt and R. W. Plush, In Statistical methods of radio wave propagation, Proc. of Svmp. University of California, Los Angeles, June 18-20, 1958 , p. 233 (Pergamon Press, New York, N.Y., 1960)

Interpretation of some features of low-frequency ionograms, J. M. Watts, J. Atmospheric and Terrest. Phys. 15, 73 (1959).

Transactions of the Joint Commission for Spectroscopy, Minutes of the Moscow Meeting, August 12-15, 1958 (Abridged), J. Opt. Soc. Am. 50, No. 4, 396 (1960).

"Ionization" of the hydrogen negative ion, S. Geltman, Proc. 4th Internatl. Conf. on Ionization Phenomena in Gases (North Holland Publishing Co., Amsterdam, The Netherlands), Uppsala 17-21, p. IA19 (1960).

Cryogenic piping system design and installation, R. B. Jacobs, Heating, Piping and Air Conditioning, p. 143 (1960).

Plan for the self-qualification of laboratories, A. T. MePherson, ASTM Bull. No. 246, 17 (1960).

The structure of $0,0^{\prime}$-diethyl methylphosphonothioate and conjugative properties of the $\mathrm{P}=\mathrm{S}$ bond, H. Finegold, J. Am. Chem. Soc. 82, No. 10, 2641 (1960).

Effect of notch geometry on tensile properties on annealed titanium at $100^{\circ}, 25^{\circ},-78^{\circ}$ and $-196^{\circ} \mathrm{C}, \mathrm{G}$. W. Geil and N. L. Carwile, Am. Soc. Testing Materials Proc. 59, 985 (1959)

How the method of rating the cooling load for refrigerated trailers has been standardized, P. R. Achenbach, C. W. Phillips, and W. F. Goddard, Am. Soc. Heating, Refgr., Air Cond. Engrs. J. 2, No. 5, 45 (1960).

The wavefront reversing interferometer, J. B. Saunders, Colloquium on Opties and Metrology, Sponsored by the International Commission of Optics, Brussels, Belgium, May 8-9, 1958, Published in Optics in Metrology, p. 227 (Pergamon Press, New York, N.Y., 1960).

Magnetoresistive effects in indium antimonide and indium arsenide, H. P. R. Frederikse and W. W. Hosler, Vol. 2, Pt. 2, of the book "Solid State Physics in Electronics and Telecommunications," p. 651 (Academic Press, New York, N.Y., 1960).
The NBS meteor burst communication system, R. J. Carpenter and G. R. Ochs, IRE Trans. Communs. Systems CS- 7 , 263 (1959)

Characteristic energy losses of electrons, L. Marton, L. B. Leder, C. Marton, and M. D. Wagner, Proc. 4th Internatl. Conf. on Electron Microscopy, September 1958, p. 281 (Berlin, Germany, 1960).

Radiation patterns of finite-size corner-reflector antennas, A. C. Wilson and H. V. Cottony, IRE Trans. on Ant. Prop. AP-8, 144 (1960).

Heat sink method for measuring the cooling loads of refrigerated structures, P. R. Achenbach and C. W. Phillips, Proc. 10th Intern. Congress of Refrigeration, August 1959, Copenhagen, Denmark (1959).

A technique for gripping high-strength fabrics during physical tests, K. F. Plitt and L. A. Dunlap, ASTM Bull. No. $246,33(1960)$.

An analysis of an absolute torsional pendulum viscometer, E. A. Kearsley, Trans. Soc. Rheology III, 69 (1959).

Radio echoes from field-aligned ionization above the magnetic equator and their resemblance to auroral echoes, K. L. Bowles, R. Cohen, G. R. Ochs, and B. B. Balsley, Letter J. Geophys. Research 65, 1853 (1960).

Measurement on the smoothness of paper, T. W. Lashof and M. Mandel, Tappi 43, No. 5, 385 (1960)

Geomagnetic and solar data, J. V. Lincoln, J. Geophys. Research 65, 1639 (1960); J. Geophys. Research 65, 1821 (1960).

The spark of originality, A. T. MePherson, The Chemist 3\%, No. 7, $275(1960)$

A simple centering jig and goniometer for punching or drilling spheres for structural models, D. K. Smith, Am. Mineralogist 45, No. 5-6, 273 (1960).

Propagation of electromagnetic pulses in a homogeneous conducting earth, J. R. Wait, Appl. Sci. Research B8, 213 (1960).

Shielded coaxial leads for low temperature electrical measurements, N. L. Brown and R. N. Barfield, Rev. Sei. Instr. 31, No. 5, $517(1960)$

Rapid impact loading of textile varns, J. C. Smith, Book, High Speed Testing, Vol. 1, p. 67 (Interscience Pub. Inc., New York, N.Y., 1960).

The absolute zenith intensity of [OI] 5577 at College, Alaska, F. E. Roach and M. H. Rees, J. Geophys. Research 65, $1489(1960)$.

Studies on sudden commencements of geomagnetic storm. using IGY data from United States stations, S. Matsushita, J. Geophys. Research 65, No. 5, 1423 (1960).

Photometric observations of the twilight glow [OI] 5577 and [OI] 6300, L. R. Megill, J. Atmospheric and Terrest. Phys. 1\%, $276(1960)$.

A study of local geomagnetic influence on the [OI] 5577 nightglow emission at Fritz Peak, J. W. McCaully, F. E. Roach, and S. Matsushita, J. Geophys. Research 65, No. 5, 1499 (1960)

Local standards laboratories, A. T. McPherson, Handb. of Electrical Measurements, 1960 ed, p. 72 (1960).

A further note on "sweepers," J. M. Watts, J. Atmospheric and Terrest. Phys. 18, 81 (1960).

The incidence equation $\mathrm{AA}^{\mathrm{t}}=\mathrm{aA}, \mathrm{K}$. Goldberg, Am. Math. Mo. 6\%, 367 (1960).

Analysis of two-factor classifications with respect to life tests, M. Zelen, Book, Contributions to Probability and Statistics, Paper 4\%, p. 508 (Stanford Univ. Press, Stanford, Calif., 1960).

Compressive properties of hard tooth tissues and some restorative materials, J. W. Stanford, K. V. Weigel, G. C. Paffenbarger, and W. T. Sweeney, J. Am. Dental Assoc. 60, No. 6, 746 (1960).

$\mathrm{OH}$ emission in the earth's atmosphere, D. M. Gates and E. Jones, Proc. 2d Natl. Infrared Information Symp. 4, 145 (1959).

Tropospheric fields and their long-term variability as reported by TASO, P. L. Rice, Proc. IRE 48, 1021 (1960).

On the power of some rank-order two-sample tests, J. R. Rosenblatt, Book, Contributions to Probability and Statistics," Paper 32, 358 (Stanford Univ. Press, Stanford, Calif., 1960). 
Disc distribution of flares associated with certain radio bursts, C. Warwick, Proc. Symp. Physical Processes in the SunEarth Environment, July 20-21, 1959 (Ottawa, Defence Research Telecommunications Establishment), DRTE Pub. No. 1025, 249 (1960).

Effect of tensile properties of reinforcement on the flexural characteristics of beams, R. G. Mathey and D. Watstein, J. Am. Concrete Inst. 31, No. 12, 1253 (1960).

The intensity of [OI] 5577 in the subauroral region as a function of magnetic activity, F. E. Roach, J. Geophys. Research 65, No. 5, 1495 (1960).
Valences of the elements in analytical procedures, J. I. Hoffman, Chem. Anal. 49, No. 1, 30 (1960).

A comparative study of absolute zenith intensities of [OI] 5577, F. E. Roach, J. W. McCaulley, E. Marovich, and C. M. Purdy, J. Geophys. Research 65, No. 5, 1503 (1960).

Publications for which a price is indicated (except for NBS Technical Notes) are available only from the Superintendent of Documents, U.S. Government Printing Office, Washington 25, D.C. (foreign postage, one-fourth additional). Technical Notes are available only from the Office of Technical Services, U.S. Department of Commerce, Washington 25, D.C. (order by PB number). Reprints from outside journals and the NBS Iournal of Research may often be obtained directly from the authors. 